\title{
Role of physical disturbance in structuring fish assemblages in seagrass beds in Port Phillip Bay, Australia
}

\author{
Sean M. Moran ${ }^{1,3, *}$, Greg P. Jenkins ${ }^{2}$, Michael J. Keough ${ }^{1}$, Jeremy S. Hindell ${ }^{2}$ \\ ${ }^{1}$ Department of Zoology, University of Melbourne, Parkville, Victoria 3010, Australia \\ ${ }^{2}$ Marine and Freshwater Resources Institute, PO Box 114, Queenscliff, Victoria 3225, Australia \\ ${ }^{3}$ Present address: Environment Protection Authority, GPO Box 4395QQ, Melbourne, Victoria 3001, Australia
}

\begin{abstract}
Disturbance in seagrass habitats may cause variation in the structure of fish assemblages and individual taxa. One important form of disturbance is wave action associated with strong winds. Total fish abundance and species richness from seagrass beds at 2 sites in Port Phillip Bay, Australia, were sampled during low and high wave disturbance. During high wave action $(>0.25 \mathrm{~m})$ in seagrass beds, abundance of fish at one site decreased significantly, but species richness was unaffected at both sites. Plankton sampling conducted at the same time as seagrass sampling (directly $300 \mathrm{~m}$ offshore from the seagrass sites) found that species richness significantly increased during high wave conditions at both sites. Total fish abundance similarly increased in the plankton during high wave conditions at one site. We conclude that variation in assemblage structure during increased physical disturbance is related to variation in a small number of numerically dominant species within the assemblage. At the individual taxon level, numerically dominant species in the seagrass and plankton showed considerable variation in response to disturbance. In the seagrass assemblage, post-larval King George whiting Sillaginodes punctata (Cuvier and Valenciennes), adult weedfish Heteroclinus perspicillatus (Cuvier and Valenciennes), and pipefish juveniles and adults from the genus Stigmatopora decreased in abundance at either one or both sites during high wave conditions. Conversely, in the plankton, adult pipefish Hypelognathus rostratus (Waite and Hale), juvenile Stigmatopora and larval Gymnapistes marmoratus (Cuvier and Valenciennes) significantly increased in abundance during these same physical conditions. It appears that for some taxa physical disturbance may facilitate secondary planktonic dispersal.
\end{abstract}

KEY WORDS: Physical disturbance $\cdot$ Fish transport - Seagrass fishes $\cdot$ Post-settlement processes Resale or republication not permitted without written consent of the publisher

\section{INTRODUCTION}

Physical disturbance at many spatial and temporal scales has the potential to cause variability in recruitment of marine invertebrates and fishes (Norcross \& Shaw 1984, Miller \& Emlet 1997, Werner et al. 1997). This disturbance-related variability can influence assemblage structure, population dynamics, and demographics of many temperate and tropical marine fishes (Milicich 1994, Thorrold et al. 1994a, Jenkins et al. 1997, Robertson et al. 1999). Assemblages of fishes from temperate seagrass beds have considerable spatial and temporal variability (Sogard et al. 1989, Ferrell

*Email: sean.moran@epa.vic.gov.au et al. 1993, Hindell et al. 2000a), which is often linked to hydrodynamics during their pre-settlement stage. For example, hydrodynamics on large (e.g. ocean currents; $100 \mathrm{~s}$ of $\mathrm{km}$ ), meso- (e.g. wind forcing, tidal currents, plumes and fronts; 10 s of $\mathrm{km}$ ) and local scales (e.g. currents, winds and waves) influence the transport and delivery of larval fish to suitable nursery habitats (Cowen 1985, Kingsford et al. 1991, Thorrold et al. 1994b, Hare \& Cowen 1996, Kingsford \& Suthers 1996). However, the importance of hydrodynamics after settlement has received less attention in explaining variability in assemblage structure and population dynamics for species residing within inshore seagrass habitats. 
Early post-settlement processes structuring marine assemblages and individual populations have largely been inferred from studies of marine invertebrates and coral reef fishes (Jones 1991, Olafsson et al. 1994, Frederick 1997, Hunt \& Scheibling 1997, Booth 2002). Postsettlement losses are poorly understood, but recent studies have suggested predation, habitat complexity, resource competition and food availability as possible causes (Shulman \& Ogden 1987, Sale \& Ferrell 1988, Connell \& Jones 1991, Hixon \& Beets 1993, Levin 1994, 1998, Carr \& Hixon 1995, Booth \& Hixon 1999). Postsettlement losses can also be influenced by the resuspension and transportation of larvae and juveniles during small-scale disturbance events. This secondary transport (from a benthic to a planktonic habitat) occurs for invertebrates such as crustacean (Blackmon \& Eggleston 2001), bivalve (Commito et al. 1995) and annelid (Cummings et al. 1995) larvae. Etherington \& Eggleston (2000) found that storm-induced waves and currents caused planktonic dispersal of recently settled crab juveniles. Similarly, post-settlement transport of bivalve species was coupled with the passive movement of sediments (Commito et al. 1995, Turner et al. 1997). In contrast, information describing the resuspension and transport of fish species from benthic marine habitats to offshore waters, particularly from temperate seagrass beds, is lacking (but see Jenkins et al. 1997).

Seagrass beds are important nursery habitats for juvenile fishes worldwide (Orth et al. 1984, Bell \& Pollard 1989, Orth 1992). At the individual bed level, early studies focused on the roles of plant density and surface area in determining the assemblage structure of fish (Heck \& Orth 1980). Orth et al. (1984) suggested that increases in structural complexity served as a refuge from predation. More recently, physical disturbance within seagrass beds has been invoked to explain variations in abundance and distributions of organisms associated with seagrass (Jenkins et al. 1997, Blackmon \& Eggleston 2001), although studies on the variation of fish in relation to disturbance are not forthcoming. Our study focuses on seagrass beds within Port Phillip Bay, Australia. Previous studies at these seagrass sites have examined the importance of larval supply (Jenkins \& May 1994, Hamer \& Jenkins 1996, Jenkins et al. 1998), habitat structure (Jenkins 1986, Jenkins \& Wheatley 1998, Jenkins et al. 1998) and predation (Hindell et al. 2000a,b) and how these factors can affect the assemblage structure of fishes. The goals of this study are: (1) to investigate whether physical disturbance in the form of increased wave heights can affect species richness and total abundance of fishes associated with shallow seagrass beds at fine temporal scales (days); and (2) to determine whether increased wave disturbance can influence secondary planktonic dispersal of individual taxa.

\section{MATERIALS AND METHODS}

Study area. Port Phillip Bay is a large (surface area of $1.95 \times 10^{9} \mathrm{~m}^{2}$ and mean depth of $12.8 \mathrm{~m}$ ), semienclosed, predominantly tidal embayment on the SE coast of Australia (Fig. 1). It is connected to the oceanic waters of Bass Strait via a narrow (3 km) rocky entrance (Black et al. 1993). The entrance to Port Phillip Bay has important implications for the hydrodynamics of the region. Driven predominantly by strong tidal currents each half tidal cycle, fast $\left(3 \mathrm{~m} \mathrm{~s}^{-1}\right)$ ebb and flood tidal jets dominate the water circulation in the entrance region (Harris et al. 1996). In the northern part of the bay the tidal currents are reduced dramatically (Rosenberg et al. 1992), and net circulation is influenced by local wind-forcing (Black et al. 1993). Currents within Port Phillip Bay also show vertical stratification (Black et al. 1993), but little thermal or chemical stratification exists (Longmore et al. 1990). The tides in Port Phillip Bay are semi-diurnal, with a range of $<1 \mathrm{~m}$.

Beds of seagrass Heterozostera tasmanica (Martens ex Aschers.) den Hartog are dispersed intermittently from the upper sublittoral margins of Port Phillip Bay to a depth of no more than $9 \mathrm{~m}$ (Bulthuis 1981). At our study sites, these beds generally consist of narrow (20 $\mathrm{m}$ wide) subtidal bands running parallel to the shore, forming a sharp boundary between seagrass and bare sand. H. tasmanica beds become more widespread within the Geelong Arm (Fig. 1) because of pro-

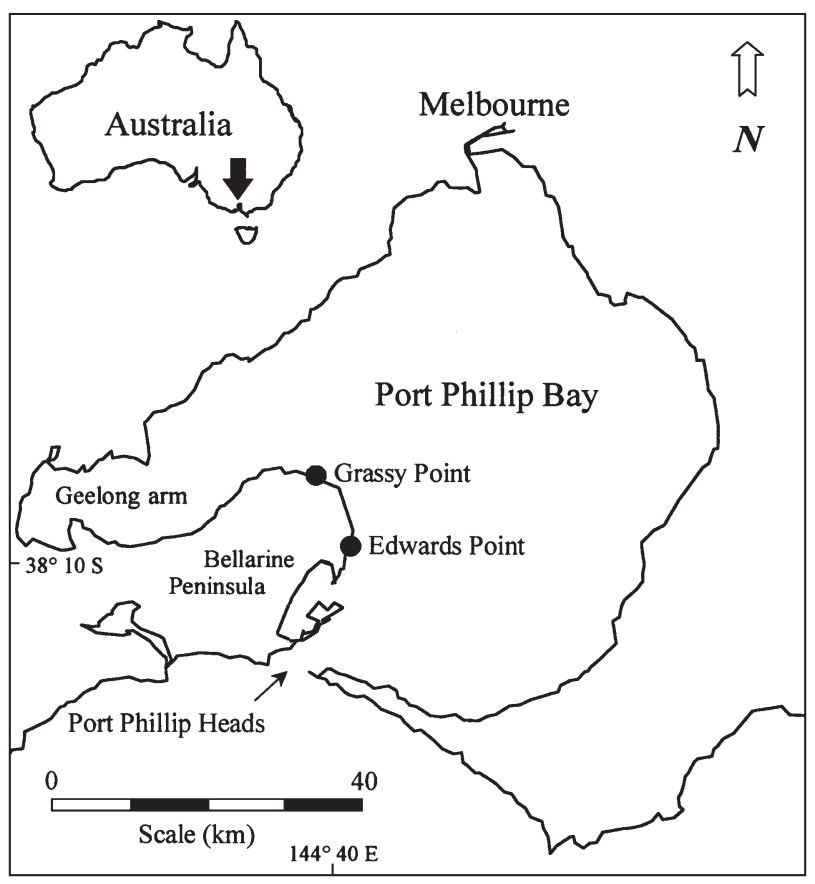

Fig. 1. Location of study sites in Port Phillip Bay, Australia 
tection from the predominant SW weather patterns and reduced currents $\left(<10 \mathrm{~cm} \mathrm{~s}^{-1}\right)$. Another seagrass species, Zostera muelleri (Irmisch ex Ascherson), also occurs in this region, but is mostly confined to the upper margins of the intertidal zone.

Field sampling. Assemblages of fishes were sampled at 2 locations (Edwards Point and Grassy Point) on the Bellarine Peninsula (Fig. 1). These 2 sites have been sampled in a number of previous studies of seagrass fish assemblages (Jenkins \& Sutherland 1997, Jenkins \& Wheatley 1998). Two habitats were sampled at each site: an inshore habitat, consisting of beds of Heterozostera tasmanica, and a planktonic habitat approximately $300 \mathrm{~m}$ offshore. The average water depth below mean low water spring (MLWS) was 0.5 and $3 \mathrm{~m}$ for the seagrass and planktonic habitats, respectively. At each site the 2 habitats were sampled during daylight and within $2 \mathrm{~h}$ either side of low tide. Both sites were sampled 23 times (i.e. 23 sampling days that represented calm and rough weather conditions) at intervals ranging between 1 and $4 \mathrm{~d}$ between September and November 2000.

Ichthyoplankton was sampled using a $1 \mathrm{~mm}^{2}$ mesh plankton net of $4 \mathrm{~m}$ length attached to a $1 \times 1 \mathrm{~m}$ steel frame. Two chain bridles were attached to the top and bottom of the frame. The top bridle was connected to a wire cable leading to the towing vessel; the bottom bridle was attached to a $16 \mathrm{~kg}$ depressor weight hung below the net. The weight was used to reduce the angle of the net while towing, thus minimising the loss in effective mouth area. The net was deployed just below the surface and towed at $1 \mathrm{~m} \mathrm{~s}^{-1}$, creating a $30^{\circ}$ angle of attack, resulting in an effective mouth area of $0.9 \mathrm{~m}^{2}$. A General Oceanics flowmeter was attached to the steel frame and suspended in the mouth of the net to estimate the volume of water filtered during each tow (standardised to $1000 \mathrm{~m}^{3}$ of water sampled). Four non-overlapping hauls, each of 10 min duration, were conducted at each site. The plankton net was retrieved whilst underway; once on board the net was washed down with seawater, and the contents of the cod end emptied into a $1 \mathrm{~mm}$ sieve. Fish and plant material were preserved in $95 \%$ ethanol.

Seagrass sampling was performed by 2 persons using a fine-mesh beach seine net (10 $\mathrm{m}$ long with a $2 \mathrm{~m}$ drop and a mesh size of $1 \mathrm{~mm}$ ). Four haphazardly placed non-overlapping hauls were taken over beds of Heterozostera tasmanica at each site. A cod end of $0.5 \mathrm{~m}$ depth was sewn into the middle of the net, and two $10 \mathrm{~m}$ ropes were attached to each end of the net. The bottom of the net was weighted by the addition of a lead tracer, and the top of the net was buoyed. The seine was deployed on foot. One person held the position, while the other fed the net out from a small inflatable boat. Upon retrieval into the inflatable, fish sam- ples were sorted from the cod end, anaesthetised in benzocaine, and preserved in $95 \%$ ethanol. Seine nets of this type have been shown to be efficient devices for sampling seagrass-associated fishes relevant to this study (Connolly 1994a, Jenkins \& Sutherland 1997).

Oceanographic parameters. Two physical parameters (wave height and wave energy) were used in our study. Wave heights were calculated by a pseudosteady wave-generation model for intertidal, enclosed estuaries of complex shape, 'Wave Generation 3 Dimensional Dispersal (WGEN3DD)' (Black \& Rosenberg 1992). The wave model incorporates wind velocity and direction, fetch, and bathymetry (Black 1996). Modelled wave heights in a $400 \times 400 \mathrm{~m}$ square immediately offshore from each site were run at hourly intervals. We averaged wave height over a $6 \mathrm{~h}$ period prior to sampling and defined 2 wave height categories: low $(<0.25 \mathrm{~m})$ and high $(>0.25 \mathrm{~m})$. We assigned these levels because wave heights $<0.25 \mathrm{~m}$ represented relatively calm surface conditions. Low wave heights were also highly correlated with offshore winds recorded at the time of sampling. Wave heights $>0.25 \mathrm{~m}$ represented more turbid, vertically mixed surface conditions highly correlated with onshore winds, recorded at the time of sampling.

Wave energy was calculated within the seagrass beds by an InterOcean S4 Electromagnetic Current Meter. Root-mean-square (RMS) values for wave-induced resultant speed $\left(\mathrm{cm} \mathrm{s}^{-1}\right)$ were averaged over the time it took to sample the seagrass beds.

Laboratory analysis. Fish were identified to the lowest taxonomic level possible (Gomon et al. 1994) and counted, and their standard lengths (SL; tip of snout to tip of caudal peduncle) were recorded. Drifting seagrass and algae collected in the plankton net (standardised weight in $\mathrm{g}$ per $1000 \mathrm{~m}^{2}$ ) were dried in an oven at $60^{\circ} \mathrm{C}$ for $48 \mathrm{~h}$ and then weighed.

Data analysis. Data were checked for normality, homogeneity of variance and collinearity prior to statistical analysis. With the exception of species richness, transformation to $\log _{10}(x+1)$ was necessary to meet the assumptions of analysis of variance (ANOVA). Replicates were pooled from each habitat (seagrass and plankton) and site (Grassy Point and Edwards Point). Because the experimental units for assessing effects of wave disturbance were days, and samples within each day were subsamples, this resulted in between 23 and 25 replicates, depending on the statistical test. Twofactor ANOVAs of site (Grassy Point/Edwards Point) and wave condition (high/low) were used to analyse species richness, total fish abundance, and individual fish abundance within each habitat. For all tests, site and modelled wave height were considered fixed factors. Analyses focused on the most abundant species. Two-factor ANOVA of site and wave condition was 
used to compare the amount of floating plant biomass in the plankton to fish abundance. Correlation analysis was used to investigate changes in species abundance under differing wave energies within seagrass beds at both sites.

Post hoc power analysis was performed on nonsignificant results using the program $G^{*}$ POWER. In our analyses, we used a range of effect sizes that we thought to be biologically important when testing the power of our main effect (wave disturbance). One abundant species, Sillaginodes punctata, whose ecology is well known in the area (Jenkins \& May 1994, Hamer \& Jenkins 1996, Jenkins et al. 1999), mostly returned significant results. We used the changes seen for this species to determine the effect size for other species prior to power analysis.

\section{RESULTS}

\section{Fish assemblages}

There was a clear distinction in the fish assemblages between sites and habitats sampled (Tables 1 \& 2). Pooling across sites and wave conditions, 49 species from 24 families were collected in the seagrass compared to 30 species from 18 families in the plankton assemblage. The numerically dominant taxa within the seagrass habitat were King George whiting post- larvae Sillaginodes punctata, 2 adult syngnathid species and juvenile syngnathids from the genus Stigmatopora, and atherinid larvae. Other common groups included clinids, gobiids and scorpaenids (Table 1). Similar dominant groups were identified in the plankton assemblage, although the pattern of these dominant groups differed markedly from the seagrass habitat (Table 2). Atherinid larvae were by far the most abundant species found in the plankton across both sites. S. punctata post-larvae were again found in moderate numbers, as were Stigmatopora juveniles and monocanthid and pleuronectid larvae.

\section{Species richness and abundance}

\section{Seagrass}

Species richness (the total number of species) within seagrass habitats did not vary between locations or between modelled wave height (Table 3, Fig. 2). In contrast, total fish abundance (total number of individuals) showed a significant 2-factor interaction where the effect of wave height varied between sites (Table 3, Fig. 2). The total number of fish collected at Grassy Point was significantly higher during calm, low wave conditions compared to high wave conditions, whereas the number of fish at Edwards Point was not significantly different between the 2 wave conditions (Fig. 2).

Table 1. Mean number (percentage) of fishes of 10 numerically abundant taxa collected per haul from seagrass beds at Edwards Point and Grassy Point during low and high wave conditions from September to November 2000

\begin{tabular}{|c|c|c|c|c|c|c|c|c|}
\hline \multirow{3}{*}{$\begin{array}{l}\text { Species } \\
\text { Sillaginidae }\end{array}$} & \multicolumn{4}{|c|}{ Edwards Point } & \multicolumn{4}{|c|}{ Grassy Point } \\
\hline & \multicolumn{2}{|c|}{ Low } & \multicolumn{2}{|c|}{ High } & \multicolumn{2}{|c|}{ Low } & \multicolumn{2}{|c|}{ High } \\
\hline & & & & & & & & \\
\hline Sillaginodes punctata post-larvae & 4.37 & $(24.1)$ & 1.48 & $(7.3)$ & 18.48 & $(36.2)$ & 3.90 & $(13.7)$ \\
\hline \multicolumn{9}{|l|}{ Syngnathidae } \\
\hline Stigmatopora nigra adults & 4.38 & $(24.2)$ & 4.65 & $(22.8)$ & 7.80 & $(15.4)$ & 3.90 & $(13.7)$ \\
\hline Stigmatopora argus adults & 1.10 & $(6.1)$ & 1.48 & $(7.2)$ & 0.80 & $(1.6)$ & 4.13 & $(14.5)$ \\
\hline Stigmatopora juveniles & 1.13 & $(6.3)$ & 2.08 & $(10.2)$ & 6.63 & $(13.1)$ & 2.28 & $(8.0)$ \\
\hline \multicolumn{9}{|l|}{ Clinidae } \\
\hline Heteroclinus perspicillatus adults & 0.22 & $(1.2)$ & 0.15 & $(0.7)$ & 5.38 & $(10.6)$ & 2.68 & $(9.4)$ \\
\hline Clinid larvae & 0.07 & $(0.4)$ & 0.70 & (3.1) & 0.00 & $(0.0)$ & 0.47 & $(1.6)$ \\
\hline \multicolumn{9}{|l|}{ Scorpaenidae } \\
\hline Gymnapistes marmoratus adults & 0.28 & $(1.6)$ & 1.00 & $(4.9)$ & 0.05 & $(0.1)$ & 0.12 & $(0.4)$ \\
\hline \multicolumn{9}{|l|}{ Gobiidae } \\
\hline Gobiid larvae & 0.87 & $(4.8)$ & 2.23 & $(10.9)$ & 0.20 & $(0.4)$ & 0.13 & $(0.5)$ \\
\hline \multicolumn{9}{|l|}{ Antherinidae } \\
\hline Atherinid larvae & 1.62 & $(8.9)$ & 2.08 & $(10.2)$ & 10.03 & $(19.8)$ & 8.06 & $(28.4)$ \\
\hline \multicolumn{9}{|l|}{ Mugilidae } \\
\hline Aldrichetta forsteri juveniles & 0.85 & $(4.7)$ & 0.35 & $(1.7)$ & 0.00 & $(0.0)$ & 0.07 & $(0.2)$ \\
\hline Total mean number of fish per haul & \multicolumn{2}{|c|}{18.12} & \multicolumn{2}{|c|}{20.38} & \multicolumn{2}{|c|}{50.70} & \multicolumn{2}{|c|}{28.45} \\
\hline Total number of species & \multicolumn{2}{|c|}{33} & \multicolumn{2}{|c|}{38} & \multicolumn{2}{|c|}{24} & \multicolumn{2}{|c|}{36} \\
\hline
\end{tabular}



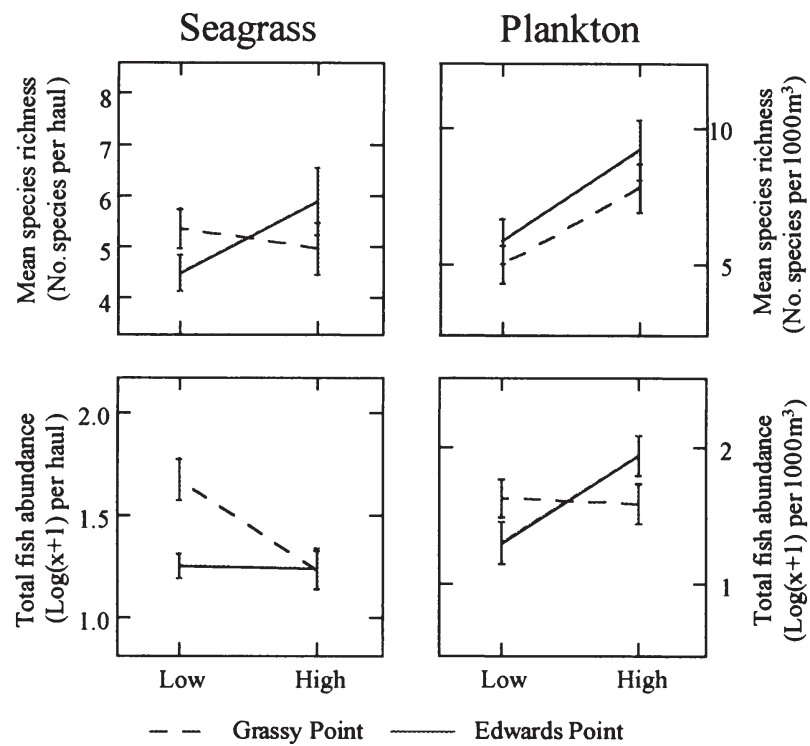

Fig. 2. Species richness and total fish abundance for wave conditions in the seagrass and plankton at Grassy Point and Edwards Point. Error bars are SE

\section{Plankton}

Wave disturbance influenced species richness in the plankton (Table 3). A greater number of species was present in the plankton across both sites during increased physical disturbance of high wave heights (Fig. 2). The total fish abundance in the plankton showed a significant wave height by site interaction (Table 3). In contrast to the seagrass habitat, this time the number of fish at Grassy Point was independent of wave height, while numbers at Edwards Point rose sharply with high wave action (Fig. 2).

\section{Individual species}

Sillaginodes punctata post-larvae (King George whiting)

Post-larvae of Sillaginodes punctata are settlement stage larvae (mean SL $=20.8 \mathrm{~mm}$ ) that have a full complement of fin elements but are yet to take on the juvenile characteristics of pigmentation, gut coiling and scale development (Bruce 1995). The abundance of $S$. punctata post-larvae showed significant differences between sites and wave heights, where the 2 factors acted independently of each other (Table 4). More fish were found at Grassy Point compared to Edwards Point, and $S$. punctata numbers were significantly higher in the seagrass during reduced wave heights (Fig. 3). Correlation analysis at Grassy Point ( $\mathrm{n}=22$, $\left.\mathrm{r}^{2}=0.310, \mathrm{p}=0.007\right)$ and Edwards Point $(\mathrm{n}=22$, $\left.\mathrm{r}^{2}=0.256, \mathrm{p}=0.016\right)$ showed numbers of $S$. punctata were negatively correlated with wave energy.

The number of Sillaginodes punctata post-larvae collected in plankton (mean SL = $19.2 \mathrm{~mm}$ ) was lower than that in seagrass (Tables $1 \& 2$ ). There was no significant difference in the abundance of $S$. punctata in

Table 2. Mean number (percentage) of fishes of 10 numerically abundant taxa (per $1000 \mathrm{~m}^{3}$ water sampled) collected from the plankton at Edwards Point and Grassy Point during low/high wave conditions from September to November 2000

\begin{tabular}{|c|c|c|c|c|c|c|c|c|}
\hline \multirow{2}{*}{$\begin{array}{l}\text { Species } \\
\text { Sillaginidae }\end{array}$} & \multicolumn{4}{|c|}{ Edwards Point } & \multicolumn{4}{|c|}{ Grassy Point } \\
\hline & \multicolumn{2}{|c|}{ Low } & \multicolumn{2}{|c|}{ High } & \multicolumn{2}{|c|}{ Low } & \multicolumn{2}{|c|}{ High } \\
\hline Sillaginodes punctata post-larvae & 3.94 & $(11.9)$ & 8.35 & $(6.6)$ & 8.81 & $(15.2)$ & 12.94 & $(20.9)$ \\
\hline Syngnathidae & & & & & & & & \\
\hline Stigmatopora nigra adults & 0.10 & $(0.3)$ & 2.55 & $(2.0)$ & 0.17 & $(0.3)$ & 0.49 & $(0.8)$ \\
\hline Stigmatopora argus adults & 0.26 & $(0.8)$ & 1.30 & $(1.0)$ & 0.08 & $(0.1)$ & 1.33 & $(2.2)$ \\
\hline Stigmatopora juveniles & 0.91 & & 13.04 & & 6.21 & & 3.05 & \\
\hline Hypelognathus rostratus adults & 1.03 & $(3.1)$ & 7.92 & $(6.3)$ & 0.61 & $(1.1)$ & 2.34 & $(3.8)$ \\
\hline $\begin{array}{l}\text { Monacanthidae } \\
\text { Acanthaluteres larvae }\end{array}$ & 0.56 & $(1.7)$ & 27.89 & $(22.3)$ & 0.09 & $(0.1)$ & 2.63 & $(4.3)$ \\
\hline $\begin{array}{l}\text { Clinidae } \\
\quad \text { Clinid larvae }\end{array}$ & 0.51 & $(1.5)$ & 4.83 & $(3.9)$ & 0.44 & $(0.8)$ & 4.35 & $(7.0)$ \\
\hline $\begin{array}{l}\text { Scorpaenidae } \\
\quad \text { Gymnapistes marmoratus larvae }\end{array}$ & 2.08 & $(6.3)$ & 9.46 & $(7.6)$ & 0.30 & $(0.5)$ & 6.21 & $(5.2)$ \\
\hline $\begin{array}{l}\text { Antherinidae } \\
\text { Atherinid larvae }\end{array}$ & 17.87 & $(54.0)$ & 41.31 & $(33.0)$ & 40.60 & $(70.1)$ & 27.07 & $(43.9)$ \\
\hline $\begin{array}{l}\text { Pleuronectidae } \\
\text { Pleuronectid larvae }\end{array}$ & 2.23 & $(6.7)$ & 1.28 & $(1.0)$ & 0.08 & $(0.1)$ & 1.96 & $(3.2)$ \\
\hline Total mean number of fish per haul & 33. & & 125 & & & & & \\
\hline Total number of species & 1 & & 2 & & & & & \\
\hline
\end{tabular}


Table 3. Two-way ANOVA comparing species richness and total fish abundance $[\log (x+1)]$ in seagrass and plankton amongst sites and wave disturbance (low and high wave heights). All tests have 1,42 degrees of freedom. Bold numbers indicate significance at $\mathrm{p}<0.05$ level

\begin{tabular}{|c|c|c|c|c|}
\hline \multirow{2}{*}{ Source } & \multicolumn{2}{|c|}{ Species richness } & \multicolumn{2}{|c|}{ Fish abundance } \\
\hline & $F$ & $\mathrm{p}$ & $F$ & $\mathrm{p}$ \\
\hline \multicolumn{5}{|l|}{ Seagrass } \\
\hline Site & 0.002 & 0.962 & 5.911 & 0.019 \\
\hline Wave & 1.144 & 0.291 & 7.126 & 0.011 \\
\hline Wave $\times$ Site & 3.649 & 0.063 & 6.203 & 0.017 \\
\hline Residual MS & 2.442 & & 0.080 & \\
\hline \multicolumn{5}{|l|}{ Plankton } \\
\hline Site & 1.606 & 0.212 & 0.007 & 0.933 \\
\hline Wave & 11.895 & 0.001 & 4.092 & 0.049 \\
\hline Wave $\times$ Site & 0.093 & 0.762 & 5.395 & 0.025 \\
\hline Residual MS & 9.084 & & 0.247 & \\
\hline
\end{tabular}

the plankton between sites or wave heights; however, the power to detect a significant effect, if one existed, was approximately $21 \%$ (Table 4, Fig. 4).

\section{Atherinid larvae (hardyhead species)}

Atherinids were generally late-stage (10 to $15 \mathrm{~mm})$, post-flexion larvae. The number of atherinid larvae collected was much higher in the plankton than in the seagrass habitat (Tables 1 \& 2). In the seagrass, atherinid numbers did not vary significantly amongst site or wave heights, nor was there an effect of wave energy (Table 4, Fig. 3). Similarly, in the plankton there was no effect of site or wave height on atherinid numbers, although unlike the high calculated power in the seagrass, the power to detect an effect of wave disturbance in the plankton was low (Table 4).

\section{Syngnathidae (pipefish species)}

High numbers of 2 species of adult pipefish, Stigmatopora argus and $S$. nigra, were collected at both sites in the seagrass. The abundance of each species at the 2 sites was similar, although the less abundant of the two, S. nigra, was much more abundant in the seagrass during low wave heights (Table 4, Fig. 3). Juveniles of the above 2 species, referred to hereafter as syngnathid juveniles, produced a significant wave by site interaction in both the seagrass and planktonic habitats (Table 4). The numbers of juveniles collected in the seagrass at Grassy Point decreased during high wave heights (Fig. 3), whereas an increase in abundance was evident during reduced wave heights in the plankton at Edwards Point (Table 4, Fig. 4). Adults of

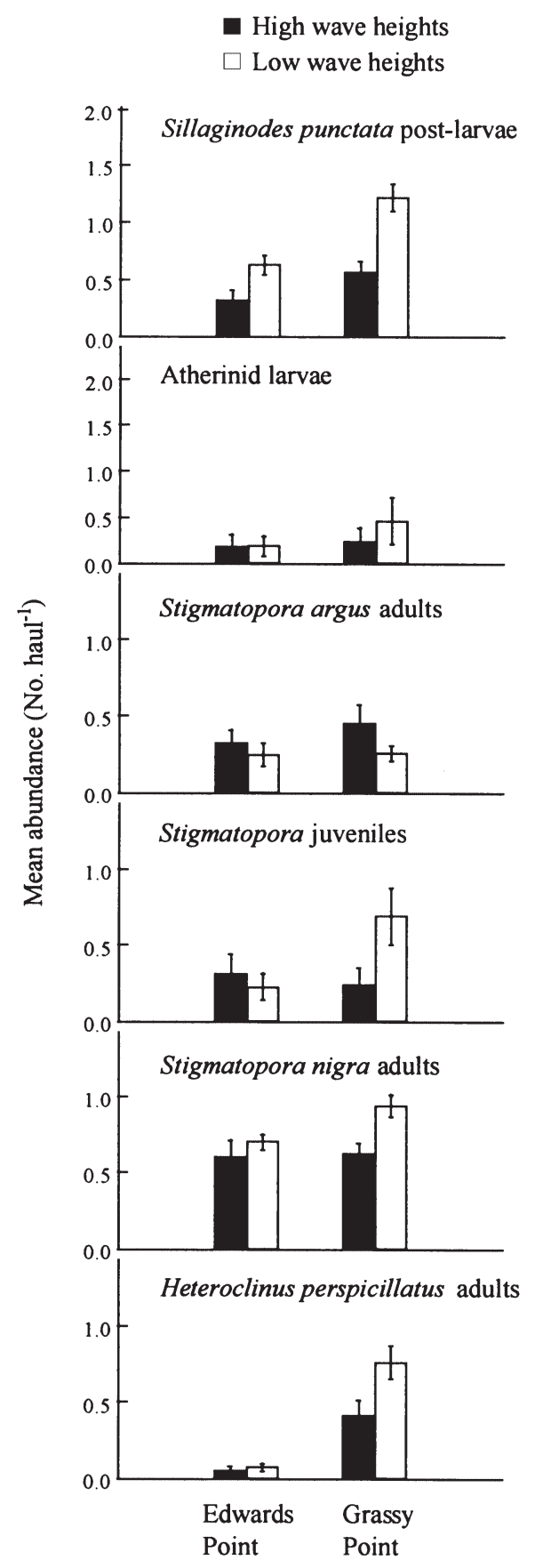

Fig. 3. Individual abundance of dominant taxa collected in seagrass during high and low wave heights. All species were $\log (x+1)$ transformed. Solid bars represent high wave heights; open bars indicate low wave heights. Error bars are SE

another syngnathid species, Hypelognathus rostratus, were predominantly found in the plankton (Tables 1 \& 2 ). The numbers of this species increased significantly in the plankton during increased wave heights (Table 4, Fig. 4). 


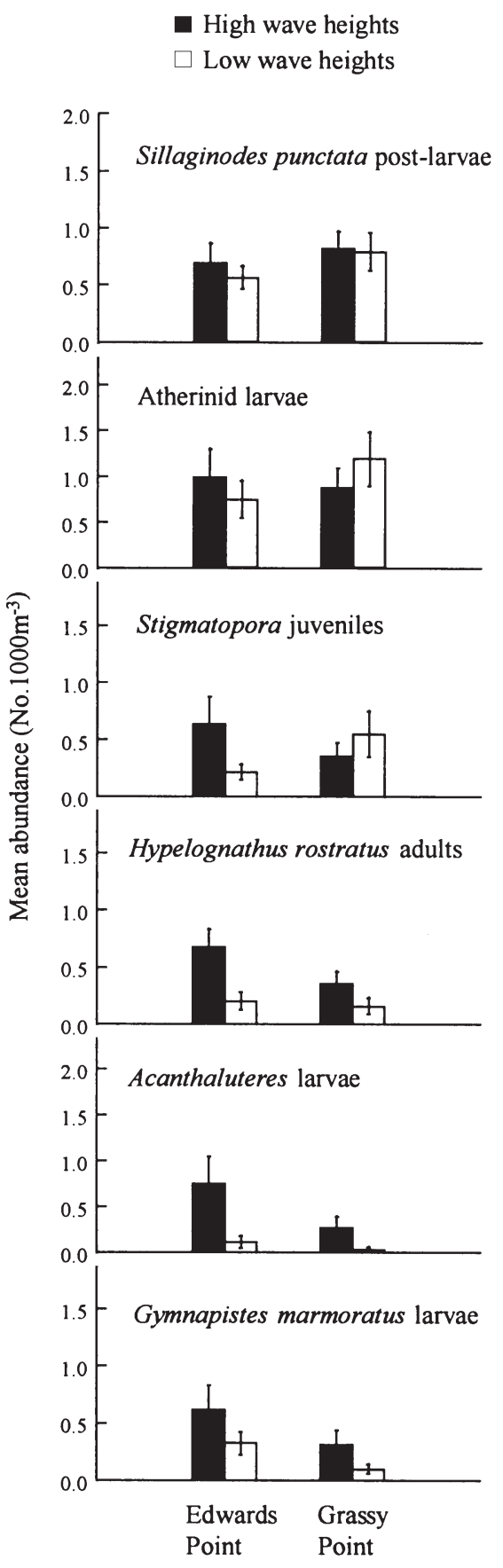

Fig. 4. Individual abundance of dominant taxa collected in the plankton during high and low wave heights. All species were $\log (x+1)$ transformed. Solid bars represent high wave heights; open bars indicate low wave heights. Error bars are SE

\section{Heteroclinus perspicillatus adults}

(spotshoulder weedfish)

The numbers of Heteroclinus perspicillatus adults in the seagrass showed a significant wave by site interaction (Table 4). More fish were collected at Grassy Point
(Table 1, Fig. 3), and the number of fish collected at Grassy Point was significantly higher during reduced wave conditions (Table 4, Fig. 3). This phenomenon was also supported by correlation analysis $(\mathrm{n}=22$, $\mathrm{r}^{2}=0.238, \mathrm{p}=0.021$ ), in which the numbers at Grassy Point were negatively correlated with wave energy.

\section{Acanthaluteres larvae (leatherjacket larvae)}

Larvae of 2 species from the monacanthid family, Acanthaluteres vittiger and A. spilomelanurus, were pooled, and their numbers analysed. These 2 species from the same genus are hereafter termed Acanthaluteres larvae. Acanthaluteres larvae were mostly well developed (post-flexion, $>10 \mathrm{~mm}$ ). These larvae were only found in the plankton, with no significant variation in numbers between sites (Table 4). At both Grassy Point and Edwards Point there was a significant increase in numbers during increased wave heights (Table 4, Fig. 4). The majority of these recruits were collected in the last $2 \mathrm{wk}$ of our study, and therefore the results for this species should be interpreted in this light.

\section{Gymnapistes marmoratus larvae (cobbler larvae)}

Larvae of this species were mostly found in the plankton, where its abundance was relatively consistent across sites (Table 2). Although not significant, slightly higher numbers of this species were collected in the plankton during high compared to low wave heights (Table 4, Fig. 4). Additionally, the power to detect an effect of wave height on this species was only approximately $24 \%$ (Table 4 ).

\section{Plant biomass}

Floating algae and seagrass gathered in the plankton net during sampling did not show any significant difference in biomass between sites (Table 5, Fig. 5). However, both algae and seagrass did show a significant change in biomass in response to wave disturbance. Significantly higher amounts of floating algae and seagrass were found on the surface during high wave heights than during low wave heights (Table 5, Fig. 5).

\section{DISCUSSION}

At our study sites, localised physical disturbance had varying effects on the fish community structure and recruitment patterns of individual taxa. At the assem- 
Table 4. ANOVA of $\log (x+1)$-transformed abundance of 6 species found in the seagrass and plankton with respect to wave condition and site. For each test the degrees of freedom are 1,44. Bold values indicate significance levels at $\mathrm{p}<0.05$

\begin{tabular}{|c|c|c|c|c|c|c|c|}
\hline \multicolumn{4}{|c|}{ Seagrass } & \multicolumn{4}{|c|}{ Plankton } \\
\hline Source & F & $\mathrm{p}$ & Power & Source & $F$ & $\mathrm{p}$ & Power \\
\hline \multicolumn{4}{|c|}{ Sillaginodes punctata post-larvae } & \multicolumn{4}{|c|}{ Sillaginodes punctata post-larvae } \\
\hline Wave & 24.997 & $<0.001$ & & Wave & 0.302 & 0.586 & $21 \%$ \\
\hline Site & 18.922 & $<0.001$ & & Site & 1.519 & 0.224 & \\
\hline Wave $\times$ Site & 3.256 & 0.078 & & Wave $\times$ Site & 0.128 & 0.722 & \\
\hline Residual MS & 0.104 & & & Residual MS & 0.238 & & \\
\hline \multicolumn{4}{|l|}{ Atherinid larvae } & \multicolumn{4}{|c|}{ Atherinid larvae } \\
\hline Wave & 0.576 & 0.452 & $81 \%$ & Wave & 0.021 & 0.885 & $13 \%$ \\
\hline Site & 1.182 & 0.283 & & Site & 0.487 & 0.489 & \\
\hline Wave $\times$ Site & 0.486 & 0.490 & & Wave $\times$ Site & 1.367 & 0.249 & \\
\hline Residual MS & 0.277 & & & Residual MS & 0.643 & & \\
\hline \multicolumn{4}{|c|}{ Stigmatopora argus adults } & \multicolumn{4}{|c|}{ Stigmatopora juveniles } \\
\hline Wave & 2.236 & 0.142 & $99 \%$ & Wave & 0.666 & 0.419 & $21 \%$ \\
\hline Site & 0.527 & 0.472 & & Site & 0.035 & 0.852 & \\
\hline Wave $\times$ Site & 0.398 & 0.531 & & Wave $\times$ Site & 4.608 & 0.037 & \\
\hline Residual MS & 0.099 & & & Residual MS & 0.235 & & \\
\hline \multicolumn{4}{|c|}{ Stigmatopora juveniles } & \multicolumn{4}{|c|}{ Hypelognathus rostratus adults } \\
\hline Wave & 2.376 & 0.130 & $99 \%$ & Wave & 10.949 & 0.002 & \\
\hline Site & 2.723 & 0.106 & & Site & 3.220 & 0.080 & \\
\hline Wave $\times$ Site & 5.031 & 0.030 & & Wave $\times$ Site & 1.873 & 0.178 & \\
\hline Residual MS & 0.161 & & & Residual MS & 0.118 & & \\
\hline \multicolumn{4}{|c|}{ Stigmatopora nigra adults } & \multicolumn{4}{|c|}{ Acanthaluteres larvae } \\
\hline Wave & 8.000 & 0.007 & & Wave & 9.100 & 0.004 & \\
\hline Site & 3.130 & 0.084 & & Site & 3.821 & 0.057 & \\
\hline Wave $\times$ Site & 2.134 & 0.151 & & Wave $\times$ Site & 1.841 & 0.182 & \\
\hline Residual MS & 0.062 & & & Residual MS & 0.241 & & \\
\hline \multicolumn{4}{|c|}{ Heteroclinus perspicillatus adults } & \multicolumn{4}{|c|}{ Gymnapistes marmoratus larvae } \\
\hline Wave & 6.158 & 0.017 & & Wave & 3.814 & 0.057 & $24 \%$ \\
\hline Site & 50.093 & $<0.001$ & & Site & 4.008 & 0.051 & \\
\hline Wave $\times$ Site & 4.868 & 0.033 & & Wave $\times$ Site & 0.084 & 0.773 & \\
\hline Residual MS & 0.063 & & & Residual MS & 0.194 & & \\
\hline
\end{tabular}

blage level, species richness in the seagrass beds remained constant during increased physical disturbance. Furthermore, species composition was similar to earlier studies on seagrass beds within Port Phillip Bay (Jenkins \& Sutherland 1997, Jenkins \& Wheatley 1998, Hindell et al. 2000a). The fact that species richness within these seagrass beds remained fairly constant during physical disturbance, and was also consistent with previous studies undertaken, suggests that fish diversity within these seagrass habitats can withstand small-scale environmental perturbations.

Compared to species richness, total fish abundance within the seagrass was shown to be highly variable during physical disturbance. At Grassy Point we found a reduction in the total number of individuals during increased wave disturbance. However, the relationship between total fish abundance and increased physical disturbance was driven primarily by a few common species within the assemblage, such as Sillaginodes punctata post-larvae, atherinid larvae, and syngnathid juveniles and adults. Previous studies in these seagrass areas have reported that these species are common and strongly contribute to the seagrass assemblage structure (Jenkins \& Sutherland 1997, Jenkins \& Wheatley 1998).

The species richness of fish in the plankton was heavily influenced by wave disturbance; a significant increase in species richness occurred during physical disturbance of high waves. Similarly, an increase in total fish abundance in the plankton was also found during increased wave heights at Edwards Point. Possible causes for these patterns may be (1) the capture of benthic or mid-water species due to vertical mixing of the water column caused by increased wave disturbance; (2) the capture of species normally found further out from our sampling site (e.g. during onshore winds, species may be transported to our sampling area by surface currents in the plankton); and (3) secondary planktonic dispersal out from the seagrass beds (see below).

The significant interaction between site and wave condition for total abundance suggests that the impact 
of wave disturbance differs at the 2 sites. In general, Edwards Point is a more exposed site than Grassy Point through greater wave fetch and stronger tidal currents. It is possible that the assemblage at Edwards Point was more resilient to disturbance, and therefore variability in disturbance had less of an impact at this site. Site differences in the plankton are more difficult to interpret because the scales of movement in the plankton would be much greater. It is possible that Edwards Point represents a hydrodynamic retention area where fish dislodged from seagrass beds accumulate in the plankton.

Similar patterns to those found at the assemblage level were also observed for individual taxa in the seagrass and planktonic habitats. During increased physical disturbance caused by high wave heights, we found 4 taxa in the seagrass decreased in numbers (e.g., Sillaginodes punctata post-larvae, syngnathid juveniles, Heteroclinus perspiculatus and $S$. nigra adults), while in the plankton 3 taxa increased abundance (Acanthaluteres larvae, Stigmatopora juveniles, and adult Hypelognathus rostratus). However, this pattern was not consistent across both sites for all species, suggesting possible mechanisms driving these patterns are variable. Mobile organisms such as fish and crustaceans have been shown to be more abundant in low-energy seagrass beds (Bell et al. 1994, Murphey \& Fonseca 1995). If we assume a relationship exists between increased physical disturbance and high-energy within seagrass beds, our results are somewhat analogous to these findings.

Resuspension of post-larvae and juveniles can initiate post-settlement transport (Rijnsdorp et al. 1985, Wang \& Xu 1997, Etherington \& Eggleston 2000, Blackmon \& Eggleston 2001). Jenkins et al. (1997) have suggested Sillaginodes punctata post-larvae

Table 5. ANOVA of $\log (x+1)$-transformed abundance of plant biomass (dry weight in $\mathrm{g}$ per $1000 \mathrm{~m}^{3}$ ) under different wave conditions at Grassy Point and Edwards Point. Degrees of freedom for both tests are 1,42. Bold numbers indicate significance level at $\mathrm{p}<0.05$

\begin{tabular}{|lrr|}
\hline Source & $F$ & \multicolumn{1}{c|}{$\mathrm{p}$} \\
\hline Algae & & \\
Wave & 25.686 & $<\mathbf{0 . 0 0 1}$ \\
Site & 1.945 & 0.170 \\
Wave $\times$ Site & 1.853 & 0.181 \\
Residual MS & 0.195 & \\
Seagrass & & \\
Wave & 21.101 & $<\mathbf{0 . 0 0 1}$ \\
Site & 0.139 & 0.711 \\
Wave $\times$ Site & 0.248 & 0.621 \\
Residual MS & 0.208 & \\
\hline
\end{tabular}

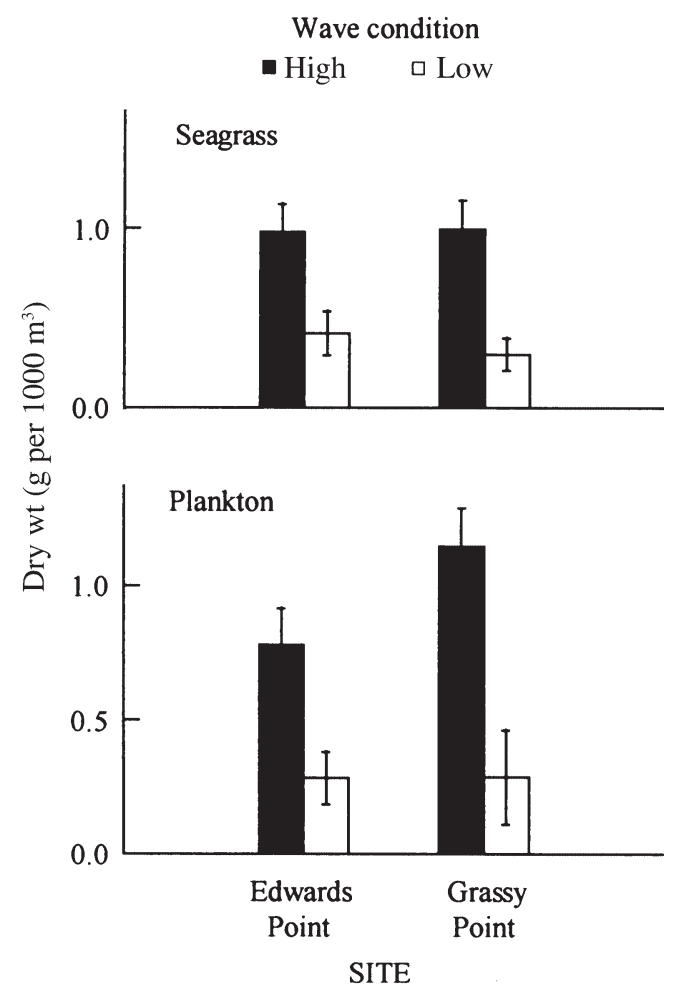

Fig. 5. Mean biomass of plant material collected from each site during high and low wave conditions. Data were $\log (x+1)$ transformed. Solid bars represent high wave heights; open bars indicate low wave heights. Error bars are SE

settling in seagrass beds near the entrance to Port Phillip Bay could be resuspended during increased physical disturbance, thus initiating secondary planktonic dispersal. Normally, onshore winds promote shoreward transport of invertebrates such as decapod larvae (Bertness et al. 1996, Clancy \& Cobb 1997) and planktonic fish larvae (Shenker et al. 1993, Thorrold et al. 1994b) to suitable settlement habitats. However, in this study we suggest that increased wave disturbance, which is highly correlated with onshore winds, has the potential to resuspend and transport a number of fish species from the seagrass into the plankton habitat. Such secondary transport may be possible through stratified horizontal currents in the water column. At our seagrass sites, recent fine-scale oceanographic studies have shown that during increased wave disturbance the current in the lower-to-middle part of the water column is directed offshore, so that small fish in that part of the water column could also be transported offshore (K. P. Black et al. unpubl. data).

Secondary transport can be evoked by behavioural (active) and/or physical (passive) mechanisms (e.g. Palmer 1988). The active process of post-larval swimming may contribute to offshore movement. In tropical 
reef systems, the possible active movement of fish larvae to onshore settlement habitats has been postulated to result from their good swimming capabilities (Stobutzki \& Bellwood 1994, 1997, Leis \& CarsonEwart 1998) and directional swimming (Leis et al. 1996, Armsworth 2000). In situ observations of postlarval Sillaginodes punctata, larval atherinids, and juvenile syngnathids obtained from close-range video analysis within seagrass beds suggests horizontal swimming abilities of these species is poor ( $\mathrm{S}$. Moran pers. obs.). For example, over extended periods of time (hours) swimming speeds of $S$. punctata have been reported to be relatively weak $\left(6 \mathrm{~cm} \mathrm{~s}^{-1}\right)$ (Welsford 1996, Jenkins \& Welsford 2002). Because of the low swimming speeds in these species, we believe active swimming in the horizontal plane alone cannot explain offshore movements from the seagrass during increased physical disturbance. In contrast, active vertical swimming up into the water column during high physical disturbance could lead to increased abundance of seagrass-associated fish in the plankton. However, the passive transport of these species may be linked to drifting seagrass and algae, of which we found a significantly higher amount in the plankton during high wave conditions. The fact that we found a number of species with a high affinity to seagrass beds (e.g. syngnathid and monacanthid species) in the plankton during these wave heights may support a theory of passive secondary transport. Planktonic transport of invertebrate and fish larvae has been linked to floating plant material (Worcester 1994, Jenkins \& Sutherland 1997, Bradbury \& Snelgrove 2001). Bell \& Westoby (1986) found a strong relationship between drifting macrophytes and syngnathids, where syngnathids can attach themselves to the upper sections of the seagrass blade (Howard \& Koehn 1985). Similarly, in our study, disturbance-related uprooting may enhance the offshore movement of this species by the same process.

The position of fish in the water column may influence the resuspension and secondary transport of our seagrass-associated fishes. Based on their vertical position in the water column, Sillaginodes punctata post-larvae and syngnathid species are thought to be associated with the top of the seagrass canopy, while the cryptic weedfish Heteroclinus perspiculatus occurs deeper within the canopy (Jenkins \& Wheatley 1998). We believe the former group to be more susceptible to secondary transport because of exposure to available offshore horizontal currents induced by the increased wave disturbance. Similar subsurface horizontal movements offshore for brown sole Pleuronectes herensteini larvae has been found during onshore winds, where larval retention was dramatically reduced (Nakata et al. 2000).
While secondary transport may be a major determinant of individual fish and assemblage patterns in the seagrass beds, post-settlement mortality may also explain the reduction of dominant taxa from this habitat. Although most studies describing post-settlement losses focus on factors such as predation (Hindell et al. 2000a), food resource limitation (Connolly 1994b), and habitat complexity (Connell \& Jones 1991), we suggest that physical injury as a result of increased physical disturbance may also contribute to post-settlement mortality in our seagrass areas. As in our study, Jenkins et al. (1997) found numbers of post-larval Sillaginodes punctata in seagrass beds to be negatively correlated with increased wave heights and suggested post-settlement mortality as a possible cause. In our case, we would expect to see higher rates of disturbance-related mortality for the smaller and lessdeveloped individuals, such as $S$. punctata $(\approx 20 \mathrm{~mm}$ SL) post-larvae and atherinid $(\approx 13 \mathrm{~mm}$ SL) larvae, which have reduced swimming capabilities. Unfortunately, in the field it would be extremely difficult to test a theory of disturbance-related mortality at such fine scales in seagrass beds.

Finally, caution must be exercised when analysing data collected during increased physical disturbance, as sampling efficiency may be compromised. Connolly (1994a) and Jenkins \& Sutherland (1997) found that net efficiency was reduced for species that are found low in the seagrass canopy compared to species that are found above it, although physical conditions (e.g. wave conditions) were not mentioned. In our study, we assume seine net efficiency was not compromised during high physical disturbance for species such as Sillaginodes punctata that are thought to position themselves above the canopy; on nearly all occasions the net sampled the complete water column, with the exception of extreme wave heights where water spilled over the top of the net. Also during these high disturbance conditions, the bottom of the net may also have slightly lifted off the substrate, affecting the catch success of species inhabiting the bottom levels of the seagrass canopy. We also assume plankton net efficiency was unaffected by increased physical disturbance. The fact that we found more fish in rough conditions compared to calm conditions may support this view.

In conclusion, our study showed that species richness remained stable during high wave disturbance in seagrass beds and increased in the plankton immediately offshore. Total fish abundance was also generally higher in the plankton, but lower in the seagrass beds during increased wave disturbance, although dominant species within each habitat seemed to drive this pattern. Investigation into the relationship between individual species and fine-scale physical disturbances 
may improve our understanding of variability in recruitment and the spatial patterns of these species during such conditions. In particular, we found secondary transport, and possibly mortality, may be a mechanism that influences the structure of individual species, depending on their spatial orientation within seagrass beds. Post-larval Sillaginodes punctata was one species that responded strongly to increased physical disturbance within seagrass beds, suggesting secondary planktonic dispersal for this species is possible. Previous modelling done on $S$. punctata has highlighted the inability of meso-scale models to accurately predict recruitment to some areas deep within Port Phillip Bay (Jenkins et al. 1999). Further investigation of these fine-scale physical processes, and how these processes may influence post-settlement transport, may improve the predictability of these models.

Acknowledgements. We thank D. Hatton for assistance with field sampling and oceanographic instrumentation. Thanks to S. Swearer, L. Morris and 3 anonymous reviewers for reading and improving earlier versions of this manuscript. The Australian Research Council provided funding for this project.

\section{LITERATURE CITED}

Armsworth PR (2000) Modelling the swimming response of late stage larval reef fish to different stimuli. Mar Ecol Prog Ser 195:231-247

Bell JD, Pollard DA (1989) Ecology of fish assemblages and fisheries associated with seagrasses. In: Larkum AWD, McComb AJ, Shepherd S (eds) Biology of seagrasses: a treatise on the biology of seagrasses with special reference to the Australian region. Elsevier, Amsterdam, p 565-609

Bell JD, Westoby M (1986) Variation in seagrass height and density over a wide spatial scale: effects on common fish and decapods. J Exp Mar Biol Ecol 104:275-295

Bell SS, Hall MO, Fonseca MS (1994) Evaluation of faunal and floral attributes of seagrass beds in high and low energy regimes: a geographic comparison. In: Dyer KR, Orth RJ (eds) Changes in fluxes in estuaries. Olsen \& Olsen, Fredensborg, p 267-272

Bertness MD, Gaines SD, Wahle RA (1996) Wind-driven settlement patterns in the acorn barnacle Semibalanus balanoides. Mar Ecol Prog Ser 137:103-110

Black KP (1996) Lagrangian dispersal and sediment transport model POL3DD. Occasional Report No. 20, Department of Earth Sciences, University of Waikato

Black KP, Rosenberg MA (1992) Natural stability of beaches around a large bay. J Coast Res 8:385-397

Black KP, Hatton D, Rosenberg M (1993) Locally and externally-driven dynamics of a large semi-enclosed bay in southern Australia. J Coast Res 9:509-538

Blackmon DC, Eggleston DB (2001) Factors influencing planktonic, post-settlement dispersal of early juvenile blue crabs (Callinectes sapidus Rathbun). J Exp Mar Biol Ecol 257:183-203

Booth DJ (2002) Distribution changes after settlement in six species of damselfish (Pomacentridae) in One Tree Island lagoon, Great Barrier Reef. Mar Ecol Prog Ser 226:157-164
Booth DJ, Hixon MA (1999) Food ration and condition affect early survival of the coral reef damselfish, Stegastes partitus. Oecologia 121(3):364-368

Bradbury IR, Snelgrove PVR (2001) Contrasting larval transport in demersal fish and benthic invertebrates: the roles of behaviour and advective processes in determining spatial pattern. Can J Fish Aquat Sci 58:811-823

Bruce BD (1995) Larval development of King George whiting, Sillaginodes punctata, school whiting, Sillago bassensis, and yellow fin whiting, Sillago schomburkii (Percoidei: Sillaginidae), from South Australian waters. Fish Bull 93: 27-43

Bulthuis DA (1981) Distribution of seagrasses in Port Phillip Bay. Marine Science Laboratories, Ministry for Conservation, Melbourne, Victoria

Carr MH, Hixon MA (1995) Predation effects on early postsettlement survivorship of coral-reef fishes. Mar Ecol Prog Ser 124:31-42

Clancy M, Cobb JS (1997) Effect of wind and tidal advection on distribution patterns of rock crab Cancer irroratus megalopae in Block Island Sound, Rhode Island. Mar Ecol Prog Ser 152:217-225

Commito JA, Thrush SF, Pridmore RD, Hewitt JE, Cummings VJ (1995) Dispersal dynamics in a wind-driven benthic system. Limnol Oceanogr 40:1513-1518

Connell SD, Jones GP (1991) The influence of habitat complexity on postrecruitment processes in a temperate reef fish population. J Exp Mar Biol Ecol 151:271-294

Connolly RM (1994a) Comparison of fish catches from a buoyant pop net and a beach seine net in a shallow seagrass habitat. Mar Ecol Prog Ser 109:305-309

Connolly RM (1994b) Removal of seagrass canopy: effects on small fish and their prey. J Exp Mar Biol Ecol 184:99-110

Cowen RK (1985) Large scale pattern of recruitment by the labrid Semicossyphus pulcher: causes and implications. J Mar Res 43:719-742

Cummings VA, Pridmore RD, Thrush SH, Hewitt JE (1995) Post-settlement movement by intertidal benthic macroinvertebrates: do common New Zealand species drift in the water column? NZ J Mar Freshw Res 29:59-67

Etherington LL, Eggleston DB (2000) Large-scale blue crab recruitment: linking postlarval transport, post-settlement planktonic dispersal, and multiple nursery habitats. Mar Ecol Prog Ser 204:179-198

Ferrell DJ, McNeill SE, Worthington DG, Bell JD (1993) Temporal and spatial variation in the abundance of fish associated with the seagrass Posidonia australis in south-eastern Australia. Aust J Mar Freshw Res 44:881-899

Frederick JL (1997) Post-settlement movement of coral reef fishes and bias in survival estimates. Mar Ecol Prog Ser 150:65-74

Gomon MF, Glover JCM, Kuiter RH (1994) The fishes of Australia's South Coast. State Print, Adelaide

Hamer PA, Jenkins GP (1996) Larval supply and short-term recruitment of a temperate demersal fish, the King George whiting, Sillaginodes punctata Cuvier and Valenciennes, to an embayment in south-eastern Australia. J Exp Mar Biol Ecol 208:197-214

Hare JA, Cowen RK (1996) Transport mechanisms of larval and pelagic juvenile bluefish (Pomatomus saltatrix) from South Atlantic Bight spawning grounds to Middle Atlantic Bight nursery habitats. Limnol Oceanogr 41:1264-1280

Harris G, Batley G, Fox D, Hall D, Jernakoff P and 6 others (1996) Port Phillip Bay Environmental Study Final Report. CSIRO, Canberra

Heck KL, Orth RJ (1980) Seagrass habitats: the roles of habitat complexity, competition and predation in structuring 
assisted fish and motile macroinvertebrate assemblages. In: Kennedy VS (ed) Estuarine perspectives. Academic Press, New York, p 449-464

Hindell JS, Jenkins GP, Keough MJ (2000a) Variability in abundances of fishes associated with seagrass habitats in relation to diets of predatory fishes. Mar Biol 136:725-737

Hindell JS, Jenkins GP, Keough MJ (2000b) Evaluating the impact of predation by fish on the assemblage structure of fishes associated with seagrass (Heterozostera tasmanica) (Martens ex Ascherson) den Hartog, and unvegetated sand habitats. J Exp Mar Biol Ecol 255:153-174

Hixon MA, Beets JP (1993) Predation, prey refuges, and the structure of coral-reef fish assemblages. Ecol Monogr 53(1):77-101

Howard RK, Koehn JD (1985) Population dynamics and feeding ecology of pipefish (Syngnathidae) associated with eelgrass beds of Western Port, Victoria. Aust J Mar Freshw Res 36:361-370

Hunt HL, Scheibling RE (1997) Role of early post-settlement mortality in recruitment of benthic marine invertebrates. Mar Ecol Prog Ser 155:269-301

Jenkins GP (1986) Composition, seasonality and distribution of ichthyoplankton in Port Phillip Bay, Victoria. Aust J Mar Freshw Res 37:507-520

Jenkins GP, May HMA (1994) Variation in settlement and larval duration of King George Whiting, Sillaginodes punctata (Sillaginidae), in Swan Bay, Victoria. Aust Bull Mar Sci 54(1):281-296

Jenkins GP, Sutherland CR (1997) The influence of habitat structure on nearshore fish assemblages in a southern Australian embayment: colonisation and turnover rate of fishes associated with artificial macrophyte beds of varying physical structure. J Exp Mar Biol Ecol 218:103-125

Jenkins GP, Welsford DC (2002) The swimming abilities of recently settled post-larvae of Sillaginodes punctata. J Fish Biol 60:1043-1050

Jenkins GP, Wheatley MJ (1998) The influence of habitat structure on nearshore fish assemblages in a southern Australian embayment: comparison of shallow seagrass, reef algal, and unvegetated habitats, with emphasis on their importance to recruitment. J Exp Mar Biol Ecol 221:147-172

Jenkins GP, Black KP, Wheatley MJ, Hatton DN (1997) Temporal and spatial variability in recruitment of a temperate, seagrass-associated fish is largely determined by physical processes in the pre- and post-settlement phases. Mar Ecol Prog Ser 148:23-35

Jenkins GP, Keough MJ, Hamer PA (1998) The contributions of habitat structure and larval supply to broad-scale recruitment variability in a temperate zone, seagrassassociated fish. J Exp Mar Biol Ecol 226:259-278

Jenkins GP, Black KP, Keough MJ (1999) The role of passive transport and the influence of vertical migration on the pre-settlement distribution of a temperate, demersal fish: model predictions compared with field sampling. Mar Ecol Prog Ser 184:259-271

Jones GP (1991) Postrecruitment processes in the ecology of coral reef fish populations: a multifactorial perspective. In: Sale PF (ed) The ecology of fishes on coral reefs. Academic Press, San Diego, p 294-327

Kingsford MJ, Suthers IM (1996) The influence of tidal phase on patterns of ichthyoplankton abundance in the vicinity of an estuarine front, Botany Bay, Australia. Estuar Coast Shelf Sci 43:33-54

Kingsford MJ, Wolanski E, Choat JH (1991) Influence of tidally induced fronts and Langmuir circulations on distribution and movements of presettlement fishes around a coral reef. Mar Biol 109:167-180
Leis JM, Carson-Ewart B (1998) Complex behaviour by coralreef fish larvae in open-water and near-reef pelagic environments. Environ Biol Fishes 53:259-266

Leis JM, Sweatman HPA, Reader SE (1996) What the pelagic stages of coral reef fishes are doing out in blue water: daytime field observations of larval behavioural capabilities. Aust J Mar Freshw Res 47:401-411

Levin PS (1994) Fine-scale temporal variation in recruitment of a temperate demersal fish: the importance of settlement versus post-settlement loss. Oecologia 97:124-133

Levin PS (1998) The significance of variable and density independent post-recruitment mortality in local populations of reef fishes. Aust J Ecol 23:246-251

Longmore AR, Cowdell RA, Gibbs CF (1990) Monitoring Port Phillip Bay water quality 1985-86

Milicich MJ (1994) Dynamic coupling of reef fish replenishment and oceanographic processes. Mar Ecol Prog Ser 110:135-144

Miller BA, Emlet RB (1997) Influence of nearshore hydrodynamics on larval abundance and settlement of sea urchins Strongylocentrotus franciscanus and S. purpuratus in the Oregon upwelling zone. Mar Ecol Prog Ser 148: 83-94

Murphey PL, Fonseca MS (1995) Role of high and low energy seagrass beds as nursery areas for Penaeus duorarum in North Carolina. Mar Ecol Prog Ser 121:91-98

Nakata H, Fujihara M, Suenaga Y, Nagasawa T, Fujii T, Van Der Veer HW, Philippart CJM (2000) Effect of wind blows on the transport and settlement of brown sole (Pleuronectes herzensteini) larvae in a shelf region of the Sea of Japan: numerical experiments with an Euler-Lagrangian model. J Sea Res 44:91-100

Norcross BL, Shaw RF (1984) Oceanic and estuarine transport of fish eggs and larvae: a review. Trans Am Fish Soc 113: 153-165

Olafsson EB, Peterson CH, Ambrose WG Jr (1994) Does recruitment limitation structure populations and communities of macro-invertebrates in marine soft sediments: the relative significance of pre- and post-settlement processes. Oceanogr Mar Biol Annu Rev 32:65-109

Orth RJ (1992) A perspective on plant-animal interactions in seagrasses: physical and biological determinants influencing plant and animal abundance. In: John DM, Hawkins SJ, Price JH (eds) Plant-animal interactions in the marine benthos. Clarendon Press, Oxford, p 147-164

Orth RJ, Heck KL, Van Montfrans J (1984) Faunal communities in seagrass beds: a review of the influence of plant structure and prey characteristics on predator-prey relationships. Estuaries 7:339-350

Palmer MA (1988) Dispersal of marine meiofauna: a review and conceptual model explaining passive transport and active emergence with implications for recruitment. Mar Ecol Prog Ser 48:81-91

Rijnsdorp AD, van Stralen M, van der Veer HW (1985) Selective tidal transport of North Sea plaice larvae Pleuronectes platessa in coastal nursery areas. Trans Am Fish Soc 114: 461-470

Robertson DR, Swearer SE, Kaupman K, Brothers EB (1999) Settlement vs. environmental dynamics in a pelagicspawning reef fish at Caribbean Panama. Ecol Monogr 69: 195-218

Rosenberg M, Hodgkinson R, Black K, Colman R (1992) In: Hydrodynamics of Port Phillip Bay. Field collection and data reduction. Victorian Institute of Marine Sciences, Melbourne

Sale PF, Ferrell DJ (1988) Early survivorship of juvenile coral reef fishes. Coral Reefs 7:117-124 
Shenker JM, Maddox ED, Wishinski E, Pearl A, Thorrold SR, Smith N (1993) Onshore transport of settlement-stage Nassau grouper Epinephelus striatus and other fishes in Exuma Sound, Bahamas. Mar Ecol Prog Ser 98:31-43

Shulman M, Ogden J (1987) What controls tropical reef fish populations: recruitment or benthic mortality? An example in the Caribbean reef fish Haemulon flavolineatum. Mar Ecol Prog Ser 39:233-242

Sogard SM, Powell GVN, Holmquist JG (1989) Spatial distribution and trends in abundance of fishes residing in seagrass meadows on Florida Bay mudbanks. Bull Mar Sci 44 (1):179-199

Stobutzki IC, Bellwood DR (1994) An analysis of the sustained swimming abilities of pre- and post-settlement coral reef fishes. J Exp Mar Biol Ecol 175:275-286

Stobutzki IC, Bellwood DR (1997) Sustained swimming abilities of the late pelagic stages of coral reef fishes. Mar Ecol Prog Ser 149:35-41

Thorrold SR, Shenker JM, Mojica R, Maddox ED, Wishinski E (1994a) Temporal patterns in the larval supply of summerrecruiting reef fishes to Lee Stocking Island, Bahamas. Mar Ecol Prog Ser 112:75-86

Editorial responsibility: Otto Kinne (Editor), Oldendorf/Luhe, Germany
Thorrold SR, Shenker JM, Maddox ED, Mojica R, Wishinski E (1994b) Larval supply of shorefishes to nursery habitats around Lee Stocking Island, Bahamas. II. Lunar and oceanographic influences. Mar Biol 118:567-578

Turner SJ, Grant J, Pridmore RD, Hewitt JE, Wilkinson MR, Hume TM, Morrisey DJ (1997) Bedload and water-column transport and colonization processes by post-settlement benthic macrofauna - does infaunal density matter. J Exp Mar Biol Ecol 216:51-75

Wang WX, Xu ZZ (1997) Larval swimming and postlarval drifting behavior in the infaunal bivalve Sinonovacula constricta. Mar Ecol Prog Ser 148:71-81

Welsford D (1996) The importance of behavioural attributes to the larval transport and recruitment of King George whiting, Sillagonodes punctata, in Port Phillip Bay. BSc (Hons.) thesis, University of Melbourne

Werner FE, Quinlan JA, Blanton BO, Luettich RA Jr (1997) The role of hydrodynamics in explaining variability in fish populations. J Sea Res 37:195-212

Worcester SE (1994) Adult rafting versus larval swimming: dispersal and recruitment of a botryllid ascidian on eelgrass. Mar Biol 121:309-317

Submitted: January 9, 2002; Accepted: November 8, 2002 Proofs received from author(s): March 11, 2003 